\title{
Validitas dan Reliabilitas Skala Psikologis Percaya Diri untuk Mengukur Tingkat Percaya Diri Siswa SMK Kota Kediri
} \author{
Program Studi Bimbingan dan Konseling, \\ Fakultas Keguruan dan Ilmu Pendidikan \\ Universitas Nusantara PGRI Kediri
}

Yuanita Dwi Krisphianti, Nora Yuniar Setyaputri, Galang Surya Gumilang ju.wahyu@gmail.com, setyaputrinora@gmail.com, galang_konselor@unpkediri.ac.id

\begin{abstract}
Abstrak
Percaya diri merupakan suatu keyakinan yang ada dalam individu yakni mampu berperilaku seperti apa yang dibutuhkan guna mendapatkan hasil sesuai dengan apa yang diharapkan. Bentuk percaya diri ditunjukkan dengan; percaya pada kemampuan pribadi, mandiri, konsep diri positif, berani mengungkapkan pendapat pribadi. Percaya diri penting ada dalam pribadi siswa SMK, hal ini karena pendidikan menengah kejuruan mengutamakan penyiapan siswa untuk memasuki lapangan kerja serta pengembangan sikap profesional. Hasil studi pendahuluan didapatkan bentuk percaya diri siswa yang kurang diantaranya a) ketika prakerin siswa malu dengan siswa yang lain, b) siswa bingung mau melakukan apa ketika lulus sekolah, c) siswa diam ketika diminta untuk berpendapat tentang masa depannya, dan d) saat praktikum siswa memilih membolos. Tujuan penelitian adalah meningkatkan percaya diri siswa SMK Kota Kediri dengan menggunakan Proses GURU. Validitas dan reliabilitas instrumen penting dilaksanakan untuk mendapatkan data yang akurat dan dapat dipertanggungjawabkan guna mengetahui tingkat percaya diri siswa SMK Kota Kediri. Pada artikel ini dibatasi sampai pada hasil validitas dan reliabilitas skala psikologi percaya diri. Berdasarkan hasil uji validitas yang disebarkan kepada 50 siswa kelas XI SMKN 2 Kediri, diperoleh 21 aitem valid dengan koefisien reliabel sebesar 0.814. Ke-21 aitem mewakili dari setiap indikator percaya diri. Berdasarkan uji validitas dan reliabilitas instrumen tersebut maka Skala Psikologis Percaya Diri dapat digunakan untuk mengukur percaya diri siswa SMK kota Kediri pada tahap penelitian selanjutnya.
\end{abstract}

Kata Kunci : skala psikologis percaya diri, percaya diri, Proses GURU

\begin{abstract}
Self confidence is a beliaef that exists in individuals that is able to behave as what is needed in order to get results in accordance with what is needed in order to get results in accordance with what is expected. The form of confidence is shown by; believe in personal abilities, independent, positive self-concept, show up personal opinions. Self confidence is important in personality of SMK students, because SMK education preparing students to enter the workforce and developing professional attitudes. The purpose of this study is to increase self confidence of SMK students in Kediri by using the GURU Process. The validity and reliability is important instruments is carried out to obtain accurate and accountable data in order to determine the level of confidence of SMK students in Kediri. This article is limited just results of validity and reliability from
\end{abstract}


Jurnal PINUS: Jurnal Penelitian Inovasi Pembelajaran, 6 (1), 2020, Yuanita Dwi Krisphianti, Nora Yuniar Setyaputri, Galang Surya Gumilang

this scale. Based on the results of the validity test distributed to 50 students, 21 valid items with a reliable coefficient of 0.814. Based on the validity and reliability test of the instrument, this scale can be used to measure the self confidence of SMK students in Kediri at the next research stage.

Keyword: psychological self confident scale, self confident, GURU process

\section{PENDAHULUAN}

Penelitian ini berawal dari fenomena yang ditemukan di SMK PGRI 4 Kediri. Terdapat beberapa fenomena yang terkait dengan rasa percaya diri rendah yang dialami oleh beberapa siswa di antaranya; a) siswa merasa tidak yakin dengan jurusan yang dipilih, b) siswa malu memilih bersekolah di SMK, c) siswa membolos ketika praktikum, d) siswa tidak percaya diri ketika praktikum berlangsung, e) siswa tidak yakin ketika lulus akan langsung mendaftar kerja, f) siswa tidak bisa menentukan akan lanjut kemana ketika lulus sekolah, g) siswa kesulitan bersaing dengan siswa dari sekolah lain ketika prakerin, dan h) siswa memilih diam ketika ditanya pendapat tentang hal apa yang akan dilakukan ketika lulus dari SMK nanti.

Berdasarkan fenomena yang tertera di atas menunjukkan bahwa siswa memiliki rasa percaya diri yang rendah. Kepercayaan diri merupakan suatu keyakinan yang dimiliki individu bahwa dirinya mampu berperilaku seperti yang dibutuhkan untuk memperoleh hasil yang direncanakan dan diharapkan (Siska, 2003). Sedangkan pendapat lain menyatakan bahwa, percaya diri adalah sifat yang ada dalam diri individu yang bukan merupakan sifat yang diturunkan (bawaan) melainkan diperoleh dari pengalaman hidup, serta dapat diajarkan dan ditanamkan melalui pendidikan, sehingga upaya-upaya tertentu dapat dilakukan guna membentuk dan meningkatkan rasa percaya diri (Siska, 2003).

Rendahnya kepercayaan diri akan membuat individu menjadi ragu-ragu, kurang bertanggung jawab, dan cemas dalam mengungkapkan pendapatnya (Irawati, 2014). Jika siswa SMK mengalami percaya diri yang rendah, maka akan menjadi bumerang untuk masa depan mereka.

Percaya diri yang rendah dikhawatirkan akan menjadi penyebab siswa kurang terampil dalam menyelesaikan masalah yang terjadi dalam dunia keja, siswa akan memiliki efikasi diri karier yang rendah, dan siswa tidak fokus terhadap pekerjaan yang ditekuni atau mudah terpengaruh oleh lingkungan. Jika hal ini terjadi, maka berbanding terbalik dengan program pemerintah yang sedang giat mencanangkan program "SMK Bisa". Program "SMK Bisa" bertujuan mencetak tenaga kerja profesional, di mana siswa SMK memang dipersiapkan sebagai tenaga siap kerja setelah lulus dari sekolah, hal ini untuk memenuhi kebutuhan dunia industri yang membutuhkan tenaga profesional dengan sumber daya manusia yang siap bersaing pada era industri 4.0. 
Jurnal PINUS: Jurnal Penelitian Inovasi Pembelajaran, 6 (1), 2020, Yuanita Dwi Krisphianti, Nora Yuniar Setyaputri, Galang Surya Gumilang

Berdasarkan latar belakang di atas, maka sangat perlu untuk melakukan perlakuan untuk meningkatkan percaya diri siswa SMK, salah satunya dengan menggunakan Proses Ground, Understand, Revise, Use (GURU). Proses GURU merupakan refleksi yang dilakukan individu dengan memunculkan pertanyaan-pertanyaan atas berbagai macam peristiwa yang telah terjadi dalam diri mereka (Silberman, 2007).

Beberapa penelitian telah membuktikan keberfungsian dari Proses GURU misalnya dengan Proses GURU keterampilan pengambilan keputusan karier siswa SMK meningkat, Proses GURU dapat meningkatkan efikasi diri karir calon konselor, serta Proses GURU terbukti lebih efektif digunakan untuk meningkatkan efikasi diri karier dibandingkan dengan FGD (Hanggara, 2016; Khususiyah et al., 2019; Krisphianti, Y.D., Setyaputri, N.Y., Puspitarini, 2019; Setyaputri, N.Y., Krisphianti, Y.D., Puspitarini, 2017; Setyaputri, N.Y., Lasan, B.B., \& Permatasari, 2016). Melalui Proses GURU siswa SMK dibantu dalam melakukan analisa terhadap situasi yang mereka alami, membuat sebuah kesimpulan merencanakan suatu hal dan melaksanakan rencana yang telah dibuat dari hasil kesimpulan.

Percaya diri dapat diartikan sebagai pengakuan individu tentang kelebihan yang dimiliki mencintai apapun yang ada dalam dirinya, dan menyadari setiap emosi yang mereka miliki (Gurler. Ismail, 2015). Percaya diri merupakan suatu hal yang penting dalam hidup individu. Adanya percaya diri yang tinggi dan bagus akan dapat membawa individu ke lingkungan sosial yang memberikan penghargaan terhadap dirinya dan selain itu individu akan dapat berinteraksi dengan baik dengan orang lain.

Menurut Lauster (Irawati, 2014) rasa percaya diri merupakan suatu sikap atau keyakinan atas kemampuan diri sendiri sehingga dalam tindakan-tindakan yang dikeluarkan tidak akan cemas, merasa bebas untuk melakukan hal-hal yang sesuai keinginan dan tanggung jawab atas perbuatannya, sopan dalam berinteraksi dengan orang lain, memiliki dorongan prestasi serta dapat mengenal kelebihan dan kekurangan diri sendiri. Ada beberapa ciri individu yang memiliki percaya diri yang bagus diantaranya; 1) percaya pada kemampuan sendiri, 2) mandiri dalam mengambil keputusan, 3) memiliki konsep diri yang positif, dan 4) berani mengungkapkan pendapat.

Berdasarkan pendapat di atas diketahui bahwa percaya diri memang harus timbul dalam diri setiap individu. Percaya diri sangatlah penting dimiliki oleh individu ketika menginginkan kesuksesan, khususnya bagi siswa SMK. Akan tetapi, tidak semua siswa SMK memiliki percaya diri yang bagus. Hal demikian akan dapat menghambat perkembangan karier mereka. salah satu cara untuk meningkatkan rasa percaya diri siswa SMK adalah dengan teknik Proses GURU.

Proses GURU merupakan teknik yang mengkombinasikan refleksi antara peristiwa yang telah dialami dengan peristiwa yang dialami sekarang oleh individu. Proses GURU ini merupakan salah satu teknik dalam pola experiential learning dan yang berisikan tentang 
Jurnal PINUS: Jurnal Penelitian Inovasi Pembelajaran, 6 (1), 2020, Yuanita Dwi Krisphianti, Nora Yuniar Setyaputri, Galang Surya Gumilang

pertanyaan-pertanyaan yang digunakan untuk refleksi.

Pada Proses GURU, peneliti dapat membuat rangkaian pertanyaan yang digunakan untuk membantu individu dalam menganalisis peristiwa yang terjadi dalam dirinya, membuat kesimpulan, membuat rencana, dan mengimplementasikan rencana yang telah dibuat.

GURU merupakan akronim dari Ground, Understand, Revise, dan Use (Silberman, 2007). Dalam penelitian ini nantinya akan menggunakan Proses GURU untuk meningkatkan percaya diri siswa SMK di Kediri. Agar mendapatkan informasi dan data yang akurat tentang percaya diri siswa, maka dibuatlah instrumen pengukuran yakni skala psikologis percaya diri. Instrumen dapat dikatakan valid dan reliabel setelah melalui uji lapangan validitas dan reliabilitas. Artikel ini diberi batasan hasil uji validitas dan reliabilitas instrumen psikologi percaya diri siswa SMK. Berikut akan disampaikan hasil dari uji validitas dan reliabilitas instrumen.

\section{METODE}

Pada penelitian ini menggunakan pendekatan kuantitatif dengan teknik penelitian quasy eksperimen. Quasy eksperimen merupakan teknik penelitian dalam pendekatan kuantitatif yang belum memenuhi persyaratan ilmiah mengikuti peraturan-peraturan tertentu (Arikunto, 2006). Adapun design penelitian yang digunakan adalah pre-test and post-test group. Adapun prosedur penelitian ini dapat dilihat sebagai berikut.

$$
\mathrm{O}_{1} \mathrm{Xr}_{2}
$$

Gambar 1. Prosedur penelitian (Cohen, L. Manion, L \& Morrison, 2007)

Keterangan:

$\mathrm{O}_{1} \quad$ : Pelaksanaan pre test dengan menggunakan skala percaya diri

X : Pelaksanaan treatment yakni dengan menggunakan Proses GURU

$\mathrm{O}_{2} \quad$ : Pelaksanaan post test dengan menggunakan skala percaya diri

Pelaksanaan penelitian ini dimulai dengan melaksanakan pre test dengan menggunakan alat pengumpul data berupa skala percaya diri. Skala percaya diri yang digunakan merupakan skala percaya diri yang telah dilakukan uji lapangan dan dilakukan uji validitas dan reliabilitas terlebih dahulu.

Siswa yang sudah melalui pre test, maka akan dapat diketahui berapa jumlah siswa yang memiliki percaya diri yang rendah. Siswa dengan percaya diri yang rendah nantinya akan menjadi subjek dalam penelitian ini. Adapun batasan siswa yang menjadi subjek dalam penelitian ini adalah 10 siswa dengan percaya diri yang rendah. Pelaksanaan treatment dilakukan dengan menggunakan Proses GURU dan selanjutnya adalah pelaksanaan post test dengan menggunakan alat pengumpul data skala percaya diri.

Alat pengumpul data yang digunakan dalam penelitian ini adalah skala percaya diri. Penyusunan skala ini dilandaskan dari indikator karakter percaya diri. Dari indikator kemudian dikembangkan menjadi blue-print skala percaya diri dan mendapat 24 aitem yang 
Jurnal PINUS: Jurnal Penelitian Inovasi Pembelajaran, 6 (1), 2020, Yuanita Dwi Krisphianti, Nora Yuniar Setyaputri, Galang Surya Gumilang

dijabarkan dari masing-masing indikator tersebut.

Uji lapangan dilaksanakan kepada siswa SMKN 2 Kediri kelas IX dengan jumlah 50 siswa. Setelah dilakukan uji lapangan selanjutnya dilakukan uji validitas dan reliabilitas. Uji validitas dengan menggunakan korelasi product moment pearson dan reliabilitas instrumen menggunakan alpha cronbach dengan bantuan SPSS20.0 for windows.

\section{HASIL}

Berdasarkan penyusunanan blue print skala percaya diri didapat 24 item yang merupakan jabaran dari indikator percaya diri. Adapun blue print skala percaya diri dapat dilihat pada tabel 1 berikut.

Tabel 1. Blue print skala psikologis percaya diri

\begin{tabular}{clll}
\hline \multicolumn{1}{c}{ Var. } & \multicolumn{1}{c}{ Indk } & \multicolumn{1}{c}{ Desk. } & $\begin{array}{c}\text { No. } \\
\text { Item }\end{array}$ \\
\hline Percaya & 1.Percaya & Mampu & 1,2, \\
Diri & $\begin{array}{l}\text { pada } \\
\text { kemampuan } \\
\text { sendiri }\end{array}$ & $\begin{array}{l}\text { melakukan } \\
\text { tugas yg } \\
\text { diberikan } \\
\text { secara }\end{array}$ \\
& & mandiri \\
\hline & 2.mandiri & Mampu & \\
& dalam & memutuskan & $, 8,9,7$ \\
& mengambil & suatu hal & 10 \\
& keputusan & tanpa & \\
& & pengaruh \\
& & orang lain &
\end{tabular}

\begin{tabular}{lll}
\hline 3.memiliki & Mampu & 11,1 \\
konsep diri & tampil apa & 2,13, \\
yang positif & adanya & 14,1 \\
& tanpa ada & 5,16, \\
& yang & 17, \\
& dibuat-buat & 18 \\
& & \\
& & \\
& & 19, \\
4.Berani & Mampu & 20, \\
mengungka & berbicara & 24 \\
pkan & apa adanya & 24 \\
pendapat & sesuai &
\end{tabular}

dengan
keadaan
diri

Tabel 2. Hasil Validitas Skala Psikologis Percaya Diri

\begin{tabular}{|c|c|c|c|}
\hline Item & $\begin{array}{l}\text { Skor r } \\
\text { hitung }\end{array}$ & $\begin{array}{l}\text { R tabel } \\
\text { N50 } \\
\text { dengan } \\
\text { taraf } \\
\text { signifikasn } \\
5 \%\end{array}$ & Simpulan \\
\hline 1 & 0.198 & 0.279 & Tidak Valid \\
\hline 2 & 0.443 & 0.279 & Valid \\
\hline 3 & 0.264 & 0.279 & Tidak Valid \\
\hline 4 & $0.661^{* *}$ & 0.279 & Valid \\
\hline 5 & $0.567^{* *}$ & 0.279 & Valid \\
\hline 6 & $0.431^{* *}$ & 0.279 & Valid \\
\hline 7 & $0.501^{* *}$ & 0.279 & Valid \\
\hline 8 & $0.352^{*}$ & 0.279 & Valid \\
\hline 9 & $0.399^{* *}$ & 0.279 & Valid \\
\hline 10 & 0.037 & 0.279 & Tidak Valid \\
\hline 11 & $0.567^{* *}$ & 0.279 & Valid \\
\hline 12 & $0.565^{* \star}$ & 0.279 & Valid \\
\hline 13 & $0.352^{*}$ & 0.279 & Valid \\
\hline 14 & $0.438^{* *}$ & 0.279 & Valid \\
\hline 15 & 0.244 & 0.279 & Valid \\
\hline 16 & $0.444^{* *}$ & 0.279 & Valid \\
\hline 17 & 0.074 & 0.279 & Tidak Valid \\
\hline 18 & $0.494^{* *}$ & 0.279 & Valid \\
\hline 19 & $0.633^{* *}$ & 0.279 & Valid \\
\hline 20 & $0.395^{* \star}$ & 0.279 & Valid \\
\hline 21 & $0.581^{* *}$ & 0.279 & Valid \\
\hline 22 & $0.583^{* *}$ & 0.279 & Valid \\
\hline 23 & $0.529^{* *}$ & 0.279 & Valid \\
\hline 24 & $0.299^{*}$ & 0.279 & Valid \\
\hline
\end{tabular}

Tabel 3. Blue print Skala Psikologis Percaya Diri setelah uji Validitas dan Reliabilitas

\begin{tabular}{llll}
\hline $\begin{array}{l}\text { Vari } \\
\text { abel }\end{array}$ & \multicolumn{1}{c}{ Indk. } & \multicolumn{1}{c}{ Desk. } & No.Item \\
\hline Perc & 1.Percaya & Mampu & $1,2,3$ \\
aya & pada & melakuka & \\
Diri & $\begin{array}{l}\text { kemampu } \\
\text { an sendiri }\end{array}$ & $\begin{array}{l}\text { yang } \\
\text { diberikan }\end{array}$ & \\
& & &
\end{tabular}


Jurnal PINUS: Jurnal Penelitian Inovasi Pembelajaran, 6 (1), 2020, Yuanita Dwi Krisphianti, Nora Yuniar Setyaputri, Galang Surya Gumilang

\begin{tabular}{|c|c|c|}
\hline & $\begin{array}{l}\text { secara } \\
\text { mandiri }\end{array}$ & \\
\hline $\begin{array}{l}\text { 2.mandiri } \\
\text { dalam } \\
\text { mengambi } \\
1 \\
\text { keputusan }\end{array}$ & $\begin{array}{l}\text { Mampu } \\
\text { memutusk } \\
\text { an suatu } \\
\text { hal tanpa } \\
\text { pengaruh } \\
\text { orang lain }\end{array}$ & $\begin{array}{l}4,5,6,7,8 \\
9\end{array}$ \\
\hline $\begin{array}{l}\text { 3.memilik } \\
\text { i konsep } \\
\text { diri yang } \\
\text { positif }\end{array}$ & $\begin{array}{l}\text { Mampu } \\
\text { tampil apa } \\
\text { adanya } \\
\text { tanpa ada } \\
\text { yang } \\
\text { dibuat- } \\
\text { buat }\end{array}$ & $\begin{array}{l}10,11,12 \\
13,14,1 \\
5,16,17\end{array}$ \\
\hline $\begin{array}{l}\text { 4.Berani } \\
\text { mengungk } \\
\text { apkan } \\
\text { pendapat }\end{array}$ & $\begin{array}{l}\text { Mampu } \\
\text { berbicara } \\
\text { apa } \\
\text { adanya } \\
\text { sesuai } \\
\text { dengan } \\
\text { keadaan } \\
\text { diri }\end{array}$ & $\begin{array}{l}18,19,20 \\
, 24\end{array}$ \\
\hline
\end{tabular}

Adapun hasil dari uji reliabilitas dapat dilihat pada tabel 4 sebagai berikut.

Tabel 4. Hasil Uji Reliabilitas

Reliability Statistics

\begin{tabular}{cr}
\hline Cronbach's Alpha & Nof Items \\
\hline 0.814 & 21
\end{tabular}

\section{PEMBAHASAN}

Berdasarkan tabel 1 yakni tentang blue print dari skala psikologis percaya diri yang belum melalui uji validitas dan reliabilitas. Dapat diketahui bahwa terdapat empat indikator yang menjadi wakil dari percaya diri siswa SMK diantaranya; 1) percaya pada kemampuan diri sendiri, 2) mandiri dalam mengambil keputusan, 3) memiliki konsep diri yang positif, dan 4) berani mengungkapkan pendapat. Dari empat indikator yang dijabarkan terdapat masing-masing indikator terwakili oleh pernyataan favourabel dan unfavourable yang mencukupi sebagai syarat terlaksananya uji validitas dan reliabilitas.

Setelah blue print skala psikologis percaya diri selesai dikembangkan, kemudian disebarkan kepada 50 siswa kelas IX SMKN 2 Kediri. Peneliti menggunakan jumlah siswa 50 karena dianggap relevan untuk menguji validitas suatu instrumen. Hal ini merujuk pada pendapat Azwar (2015) yang mengatakan bahwa syarat minimal dari jumlah subjek uji validitas adalah $2 \mathrm{x}$ dari jumlah pernyataan atau aitem yang telah dikembangkan.

Setelah disebar, kemudian diuji dengan menggunakan korelasi product moment pearson, diketahui hasil aitem yang valid adalah 21 aitem dan 3 aitem tidak valid. Hasil telah dijabarkan pada tabel 2 di atas. Berdasarkan tabel 2 tentang hasil validitas skala psikologis percaya diri di atas, terdapat aitem yang kurang dari $\mathrm{r}$ hitung, yakni aitem nomor 1, 3, 10, dan 17. Akan tetapi ada satu aitem yakni nomor 3 yang dalam hal ini peneliti tetap mempertahankan karena nilai $r$ hitung hampir mendekati dari $r$ tabel yang telah ditentukan. Dengan catatan peneliti akan mengoreksi atau merevisi kembali aitem yang mungkin membuat siswa bingung hingga data yang didapatkan tidak sesuai. Sedangkan untuk aitem nomor 1, 10, dan 17 akan peneliti delete karena $\mathrm{r}$ hitung jauh dari $\mathrm{r}$ tabel yang telah ditentukan yakni 0.279 . Oleh karena itu, aitem yang dinyatakan valid dalam penelitian ini terdapat 21 aitem.

Hal yang dilakukan peneliti terhadap aitem yang dinyatakan valid adalah peneliti mulai menyusun kembali nomer aitem yang dinyatakan valid 
Jurnal PINUS: Jurnal Penelitian Inovasi Pembelajaran, 6 (1), 2020, Yuanita Dwi Krisphianti, Nora Yuniar Setyaputri, Galang Surya Gumilang

sehingga skala dapat digunakan sebagaimana mestinya. Adapun blue print skala percaya diri setelah uji validitas dan reliabilitas dapat diketahui melalui tabel 3.

Berdasarkan tabel 3 yakni tentang Blue print Skala Psikologis Percaya Diri setelah uji Validitas dan Reliabilitas, penyusunan kembali blue print skala psikologis percaya diri dapat diketahui bahwa masing-masing indikator percaya diri telah terwakili dengan aitem yang valid. Selanjutnya untuk menilai kereliabelan dari skala ini dilanjutkan dengan melakukan uji reliabel dengan menggunakan alpha cronbach dengan bantuan SPSS 20.0 for windows.

Berdasarkan hasil uji reliabilitas skala didapatkan hasil Alpha cronbach sebesar 0.814. Hal ini memiliki arti bahwa nilai koefisien reliabilitas skala psikologis percaya diri dalam rentang reliabel. Pernyataan ini didasarkan pada pendapat Azwar (2015) yang mengatakan bahwa koefisien reliabel yang mendekati 1.00 memiliki arti pengukuran instrumen semakin reliabel. Dengan demikian, skala psikologis percaya diri dapat digunakan sebagai instrumen percaya diri siswa SMK di Kota Kediri dalam tahap penelitian selanjutnya, yakni untuk mendapatkan data tentang siapa saja siswa SMK yang memiliki percaya diri yang rendah.

Instrumen penelitian adalah suatu alat yang digunakan untuk mengumpulkan data atau mengukur objek dari suatu variabel penelitian. Nilai validitas dan reliabilitas suatu instrumen dipengaruhi oleh subjek yang diukur, pengguna instrumen, dan instrumen itu sendiri, oleh karena itu validitas dan reliabilitas harus selalu diuji sebelum instrumen digunakan (Yusup, 2018).

Ada pendapat lain juga yang mendukung tentang pentingnya uji validitas dan reliabilitas yakni menurut (Widodo, 2006) yang berpendapat bahwa hasil dari uji validitas dan reliabilitas penelitian merupakan bukti yang mendukung atau sebaliknya tidak mendukung dari sebuah instrumen yang diukur. Berdasarkan dua pendapat tersebut, maka benar uji validitas dan reliabilitas pada sebuah instrumen penelitian harus dilakukan guna untuk mendapatkan instrumen yang relevan terhadap variabel penelitian.

Hasil penelitian yang menunjukkan validasi dan reliabilitas skala ini, semakin memperkuat penelitian terdahulu tentang penggunaan Proses GURU yang juga diterapkan pada variabel penelitian lainnya, misalnya penggunaan Proses GURU untuk meningkatkan efikasi diri karier mahasiswa S1 BK (Setyaputri, N.Y., Krisphianti, Y.D., Puspitarini, 2017) dan penggunaan Proses GURU untuk meningkatkan pengambilan keputusan pada siswa SMK (Hanggara, 2016).

\section{SIMPULAN}

Berdasarkan perihal yang telah dijelaskan di atas dapat diketahui bahwa meningkatkan percaya diri siswa SMK Kota Kediri menggunakan Proses GURU membutuhkan sebuah instrumen pengumpul data yang relevan. Instrumen tersebut berupa skala psikologis percaya diri. Skala psikologis percaya diri dikembangkan berdasarkan indikator ahli dan telah dilakukan uji validitas dan reliabilitas. 
Jurnal PINUS: Jurnal Penelitian Inovasi Pembelajaran, 6 (1), 2020, Yuanita Dwi Krisphianti, Nora Yuniar Setyaputri, Galang Surya Gumilang

Berdasarkan hasil uji validitas dan reliabilitas instrumen, diperoleh 21 aitem yang telah mewakili dari setiap indikator yang dikembangkan dengan koefisen reliabel instrumen sebesar 0.814 . Berdasarkan dari uji tersebut, maka skala psikologis percaya diri dapat digunakan sebagai alat ukur percaya diri siswa SMK Kota Kediri pada tahap penelitian selanjutnya

\section{DAFTAR RUJUKAN}

Azwar, S. (2015). Penyusunan Skala Psikologi (2nd ed.). Pustaka Belajar.

Cohen, L. Manion, L \& Morrison, K. (2007). Research Methods in Education Sixth edition. New York: Routledge Taylor \& Francis Group.

Gurler. Ismail. (2015). Correlation between Selfconfidence and Speaking Skill of English Language Teaching and English Language and Literature Preparatory Students. Curr Res Soc Sci, 1, 14-19.

Hanggara, G. (2016). Keefektifan "Proses Guru" sebagai Teknik Bimbingan Kelompok dalam Meningkatkan Pengambilan Keputusan Karier Siswa SMK. Jurnal Kajian Bimbingan Dan Konseling.

https://doi.org/10.17977/um001v1i4 2016p148

Irawati. (2014). Peran Pemberian Layanan Bimbingan Pribadi Dalam Meningkatkan Percaya Diri Siswa Dari Papua Kelas X-7 SMAN 3 Kediri Tahun Pelajaran 2013/2014. Universitas Nusantara PGRI Kediri.

Khususiyah, K., Setyaputri, N. Y., Gumilang, G. S., \& Nawantara, R. D. (2019). Penggunaan Proses GURU (Ground, Understand, Revice, Use) untuk Meningkatkan Efikasi Diri Karier Mahasiswa Calon Guru BK. Nusantara of
Research: Jurnal Hasil-Hasil Penelitian Universitas Nusantara PGRI Kediri. https://doi.org/10.29407/nor.v6i1.1 3449

Krisphianti, Y.D., Setyaputri, N.Y., Puspitarini, I. Y. . (2019). Perbedaan Antara Penggunaan Focus Group Discussion (FGD) Dengan Proses Ground, Understand, Revise, and Use (GURU) Terhadap Efikasi Diri Karier Mahasiswa S1 Bimbingan dan Konseling. Nusantara of Research: Jurnal Hasil-Hasil Penelitian Universitas Nusantara PGRI Kediri, 6(1), 33-40.

Setyaputri, N.Y., Krisphianti, Y.D., Puspitarini, I. Y. . (2017). Peningkatan Efikasi Diri Karier Mahasiswa S1 Bimbingan dan Konseling UN PGRI Kediri Melalui Paket Pelatihan GURU-Karier. Jurnal Nusantara of Research, 4(2), 93-99.

http://ojs.unpkediri.ac.id/index.php/ efektor/article/view/891

Setyaputri, N.Y., Lasan, B.B., \& Permatasari, D. (2016). Pengembangan Paket pelatihan "Ground, Understand, Revise, Use (GURU)-Karier" untuk Meningkatkan Efikasi Diri Karier Calon Konselor. Jurnal Kajian Bimbingan Dan Konseling, 1(4), 132-141.

Silberman, M. (2007). The Handbook of Experiential Learning. San Fransisco: John Wiley \& Sons. Inc.

Siska, S. \& E. H. P. (2003). Kepercayaan Diri Dan Kecemasan Komunikasi Interpersonal Pada Mahasiswa. JURNAL PSIKOLOGI, 2, 67-71.

Widodo, P. B. (2006). Reliabilitas dan Validitas Konstruk Skala Konsep Diri untuk Mahasiswa Indonesia. Jurnal Psikologi Universitas Diponegoro, 3(1).

Yusup, F. (2018). Uji Validitas dan 
Jurnal PINUS: Jurnal Penelitian Inovasi Pembelajaran, 6 (1), 2020, Yuanita Dwi Krisphianti, Nora Yuniar Setyaputri, Galang Surya Gumilang

Reliabilitas Instrumen Penelitian Kuantitatif. Tarbiyah: Jurnal Ilmiah Kependidikan, 7(1), 17-23. 